\title{
Molecular analysis of the benthos microbial community in Zavarzin thermal spring (Uzon Caldera, Kamchatka, Russia)
}

\author{
Alexey S Rozanov', Alla V Bryanskaya', Tatiana K Malup', Irina A Meshcheryakova', Elena V Lazareva², \\ Oksana P Taran ${ }^{3}$, Timofey V Ivanisenko ${ }^{1}$, Vladimir A Ivanisenko ${ }^{1,4}$, Sergey M Zhmodik ${ }^{2,4}$, Nikolay A Kolchanov,4, \\ Sergey E Peltek ${ }^{1 *}$
}

From IX International Conference on the Bioinformatics of Genome Regulation and StructurelSystems Biology (BGRSISB-2014)

Novosibirsk, Russia. 23-28 June 2014

\begin{abstract}
Background: Geothermal areas are of great interest for the study of microbial communities. The results of such investigations can be used in a variety of fields (ecology, microbiology, medicine) to answer fundamental questions, as well as those with practical benefits. Uzon caldera is located in the Uzon-Geyser depression that is situated in the centre of the Karym-Semyachin region of the East Kamchatka graben-synclinorium. The microbial communities of Zavarzin spring are well studied; however, its benthic microbial mat has not been previously described.

Results: Pyrosequencing of the V3 region of the 16S rRNA gene was used to study the benthic microbial community of the Zavarzin thermal spring (Uzon Caldera, Kamchatka). The community is dominated by bacteria (>95\% of all sequences), including thermophilic, chemoorganotrophic Caldiserica (33.0\%) and Dictyoglomi (24.8\%). The benthic community and the previously examined planktonic community of Zavarzin spring have qualitatively similar, but quantitatively different, compositions.

Conclusions: In this study, we performed a metagenomic analysis of the benthic microbial mat of Zavarzin spring. We compared this benthic community to microbial communities found in the water and of an integral probe consisting of water and bottom sediments. Various phylogenetic groups of microorganisms, including potentially new ones, represent the full-fledged trophic system of Zavarzin. A thorough geochemical study of the spring was performed.
\end{abstract}

\section{Background}

Microbial communities in geothermal areas are of great interest in a variety of fields, including ecology, microbiology and medicine. They have the potential to answer fundamental questions, as well as those with practical benefits [1-4]. The microbiology of these geothermal habitats has been studied during the last few decades $[5,6]$. Classical microbiology techniques can only be used to study microorganisms that can be cultured; however,

\footnotetext{
*Correspondence: peltek@bionet.nsc.ru

${ }^{1}$ Institute of Cytology \& Genetics SB RAS, Novosibirsk, 630090, Russia

Full list of author information is available at the end of the article many microbial species, including those from thermal habitats, cannot be cultured in the laboratory. There is a growing realization that uncultured microbiota are untapped resources for basic and applied research. Modern molecular biology techniques have revealed a species richness of microbial systems that has far surpassed that which was expected based on the use of traditional microbiological techniques. The earliest studies of microbial communities in Yellowstone National Park (USA) using analyses of 16S rRNA genes resulted in the detection of many novel, unculturable microorganisms that are active at high temperatures $[7,8]$. 
Microbial communities in Kamchatka (Russia) thermal springs have been studied since the 1960s using traditional microbiology methods based on morphology, physiology and biochemistry of the indigenous microorganisms [9].

Subsequent studies of the microbial communities in Kamchatka used more modern molecular biological approaches [10-15] Thus, numerous phylogenetically diverse microorganisms were found in the waters of Zavarzin spring (caldera of the Uzon volcano in the Kronotsky Nature Reserve). Zavarzin is prominent among the Uzon thermal springs. It is a large, deep pool with fine blue sediment and thick layers of sulphur deposits, and microbial communities have developed along its creek $[16,17]$.

Water samples from the Zavarzin thermal spring have only recently been characterized [16]. A metagenomic study of integral water and sediment samples collected from two thermal outlets of the Uzon caldera, Arkashin Shurf and Zavarzin thermal spring, has been performed [17]. The composition of water samples from Zavarzin thermal spring has recently been determined by pyrosequencing [16].

Our aim here was to study the metagenome of the Zavarzin benthic microbial community by $16 \mathrm{~S}$ rRNA pyrosequencing, and to compare the microbial communities found in the water and the benthos in Zavarzin.

There are two major thermal outlets in Kamchatka, the Uzon caldera and the Geyser Valley. We performed our studies in the Uzon caldera. The Uzon-Geyser depression is located in the centre of the Karym-Semyachin region of the East Kamchatka graben-synclinorium. Uzon caldera is located in the western part of the depression. The caldera of the Uzon volcano is a $150-\mathrm{km}^{2}$ depression about $10 \mathrm{~km}$ in diameter. One of the largest craters made by a volcanic eruption in Kamchatka, which resulted in the formation of Dalneye Lake, is $1.65 \mathrm{~km}$ in diameter and is situated in the eastern part of the caldera. This part of the caldera is swampy; several lakes are located there, of these Dalneye is the largest. Multiple springheads of the Shumnaya River flow through the caldera.

Uzon caldera is filled with lake sediments and pumice. Lake sediments are represented by aleuropelitic tuffs and various pumice sands formed at the bottom of volcanic lakes. Dacite extrusions formed at the same tame as lake sediments; the closest extrusion to the Uzon thermal anomaly is Belaya Mountain. Glacial moraines formed during the last glaciation, and peatbog deposits are Holocene deposits. Talus-proluvial gravel-pebble deposits are also found there [18].

In Uzon, recent hydrothermal activity is manifested by outlets of overheated water that produces a zone of local surface warming in its northeastern part. This is the most depressed and swampy part of the caldera. Thermal activity is confined to several regions of various sizes, scattered over an area of about $15 \mathrm{~km}^{2}$. There are five thermal fields in the Uzon caldera: South, West, North, Orange and East (Figure 1). The East thermal field is the largest of the five. All types of surface hydrothermal activity are found there: hot springs, water and dirt pools, dirt volcanoes, fumaroles, etc. The field is $1.5 \mathrm{~km}$ long, and the heated zone is $200-400 \mathrm{~m}$ wide [19]. The field may be divided into three sectors.

All water types characteristic of recent volcanic hydrothermal fields are found in the Uzon caldera. Overheated chloride-sodium solutions are discharged in sector II of the East thermal field (Figure 1), which is characterized by high concentrations of boron, arsenic, antimony, mercury and lithium. The main ore body, consisting mostly of realgar, orpiment, antimonite, pyrite, cinnabar and metacinnabar, is located within sector II [18-20]. The others water types (chloride-sulphate, sulphate-chloride, sulphate and bicarbonate) are believed to be formed by complex processes of the differentiation of highly mineralized chloride-sodium solutions, as well as by its mixing with acid solutions formed by the oxidation of sulphide material and surface hydrocarbonate water. The water of Zavarzin thermal spring located in the extreme south of sector I of the East thermal field, far from the discharge of the main thermal solutions, is precisely the product of such a mixing.

\section{Results and discussion \\ Object of the study}

Zavarzin is a round pool about $3 \mathrm{~m}$ in diameter, enclosed in caldera lake sediments. The bottom of the pool is covered with loose, fine, milk-cream-coloured native sulphur bottom sediment. Green cyanobacterial communities are found along the edge of the pool and the course of the stream (Figure 2).

Zavarzin and its microbial communities have been described in detail elsewhere [16,17]. However, the benthic microbial mat, which we found serendipitously in the fall of 2010 when sampling bottom sediments, has not been described.

\section{Zavarzin water content}

The Zavarzin thermal spring water temperature is $56-58^{\circ} \mathrm{C}$ and the $\mathrm{pH}$ is 6.6 , which is at the boundary between neutral and acidic water (Table 1). The total dissolved solids (TDS) is $410 \mathrm{mg} / \mathrm{l}$. Its water content is complex: although sodium and hydrocarbonate ions prevail, the content of magnesium, calcium and sulphates is also very high, as is its silica content. As in the Uzon caldera, the water is a sodium chloride hydrothermal solution, with high concentrations of Li (47 ppb), B (980 ppb), Mn (610 ppb), As (22 ppb), Br (47 ppb), I (6 ppb), Cs (2.4 ppb) and Ba (98 ppb). The high contents of $\mathrm{Al}(33 \mathrm{ppb}), \mathrm{P}(160 \mathrm{ppb})$ and $\mathrm{Fe}(16 \mathrm{ppb}$,$) in the Zavarzin thermal spring water$ 


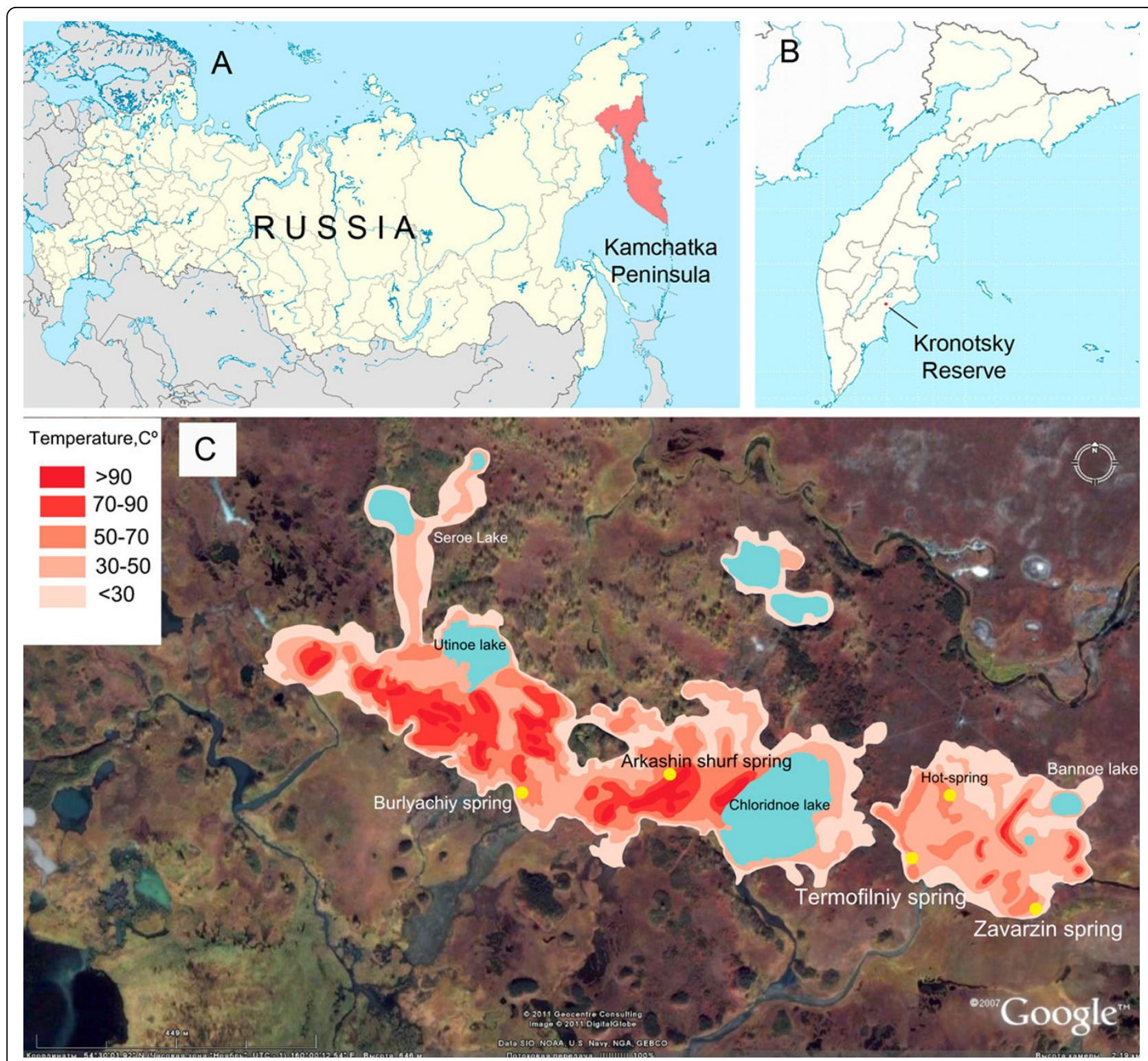

Figure 1 Location of the Zavarzin thermal spring. A, B - A map that shows the location of the Kronotsky reserve, Kamchtka Russia. C - A schematic thermometrical map of the East field in the Uzon caldera, Kamchatka, Russia.

possibly result from a mixed solution formed by the oxidation of sulphides. As in all springs of the Uzon caldera, the concentration of Ag is high (0.8 ppb).

\section{Mineral content of bottom sediments and the microbial community}

As mentioned above, the bottom of Zavarzin is covered with highly dispersed sulphur particles, which have a sphere-like, drop-like or elongated shape (Figure 3a). No faceted crystals are observed. This sulphur layer also includes grains of amorphous silica and the detritus of lake sediments that fill the Uzon caldera. Clusters of well-faceted prismatic crystals of gypsum often occur under the sulphur layer (Figure 3b).
The mineral content of the organomineral aggregate of the benthic microbial community is more diverse. A considerable amount of igneous rock detritus is found among bacterial filaments and diatom shells (Figure 3c). In addition, there are local areas of silicification and many sphere-like pyrite coalescences (possibly framboids) up to $10 \mu \mathrm{m}$ in diameter. Well-faceted, octahedral pyrite crystals (up to $5 \mu \mathrm{m}$ in diameter) are occasionally found.

\section{Elemental content of the bottom sediments and microbial community}

Table 2 presents the elemental contents of Zavarzin gryphon walls that are represented by fragmented lake 


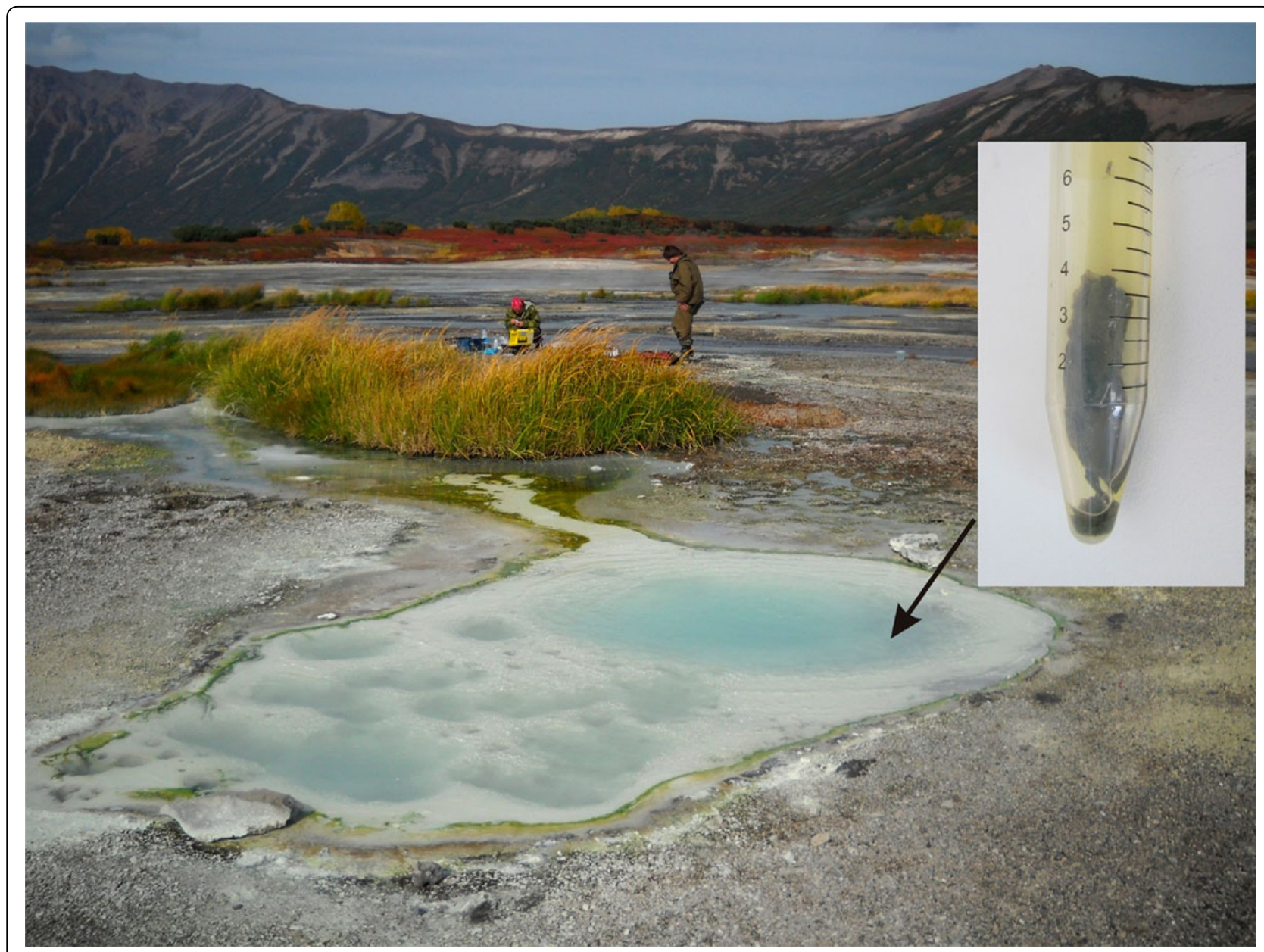

Figure 2 Zavarzin thermal spring. Arrow indicates the sampling site.

deposits (enclosing sediments), highly dispersed sulphur bottom sediments precipitated from water, a benthic microbial community and a cyanobacterial community living along the edge of the gryphon. In comparison to enclosing sediments, highly dispersed sulphur bottom sediments are characterized by much higher contents of $\mathrm{Sb}$ and $\mathrm{Te}$, about the same concentrations of $\mathrm{Ni}, \mathrm{Cu}, \mathrm{Br}$ and As, and lower concentrations of other elements; the $\mathrm{Hg}$ content is $190 \mathrm{ppm}$. We used the logarithm of the ratio of the content of an element in the sediments (Cs) to its content in water $(\mathrm{Cw})$ to compare these phases. The $\log (\mathrm{Cs} / \mathrm{Cw})$ ranged from 1 to 3 for the elements that are mobile in these conditions: alkaline and alkaliearth elements $(\mathrm{Na}, \mathrm{Ca}, \mathrm{Rb}, \mathrm{Sr}, \mathrm{Cs}, \mathrm{K})$, anionic elements (Ge, Se, V, As), halogenides (Br and I), as well as $\mathrm{Mn}$ and $\mathrm{Zn}$. For such elements as $\mathrm{Cr}, \mathrm{Co}, \mathrm{Mo}, \mathrm{Ad}$ and $\mathrm{Pb}$, the contents in sediments exceeds that in water by four orders of magnitude, while the contents of $\mathrm{Fe}, \mathrm{Ni}, \mathrm{Cu}$, $\mathrm{Ga}, \mathrm{Cd}, \mathrm{Sn}, \mathrm{Sb}, \mathrm{Te}, \mathrm{Hg}$ and $\mathrm{U}$ were five orders of magnitude greater. $\mathrm{Ti}, \mathrm{Y}, \mathrm{Zr}, \mathrm{Nb}$ and $\mathrm{Th}$ are the least mobile elements (Table 2). The elemental content of the cyanobacterial community found along the edge of the gryphon is identical to that of sulphur layer.

The concentration of most elements in the biomineral aggregate of the benthic community is close to that of the sandy material of gryphon walls. By calculating the logarithm of the ratio of the content of an element in the biomineral aggregate $(\mathrm{Cc})$ to that in water $(\mathrm{Cw})$, we can see that the contents of $\mathrm{Br}$ and $\mathrm{Se}$ in the community aggregate are higher than those in water by three orders of magnitude; by four for $\mathrm{As}$; by five for $\mathrm{Cu}$ and $\mathrm{Sb}$; and by six for $\mathrm{Hg}$. This enrichment may be explained by sorption of the elements by the organic substance of the community and their subsequent fixation as sulphide minerals. An excess of sulphide ions may be due to sulphate-reducing bacteria. Additionally, one cannot exclude the specific accumulation of mercury by certain members of the microbial community. In earlier studies [19], the highest $\mathrm{Hg}$ content in the Uzon caldera was found in the sediments of Chloridnoye Lake near water gryphons. This implies that the history of its formation was the same as we observed for Zavarzin. We suggest 
Table 1 Zavarzin water content

\begin{tabular}{|c|c|c|c|c|c|}
\hline $\begin{array}{l}\text { Elemental } \\
\text { composition }\end{array}$ & Units & $C_{w}$ & $\begin{array}{l}\text { Elemental } \\
\text { composition }\end{array}$ & Units & $C_{w}$ \\
\hline Temperature & ${ }^{\circ} \mathrm{C}$ & 58 & $\mathrm{Ga}$ & $\mathrm{ppb}$ & 0.13 \\
\hline $\mathrm{pH}$ & $\mathrm{pH}$ & 6.62 & $\mathrm{Ge}$ & $\mathrm{ppb}$ & 0.7 \\
\hline Eh & $\mathrm{mV}$ & 54 & As & $\mathrm{ppb}$ & 22 \\
\hline $\mathrm{DOC}$ & ppm & 1.0 & $\mathrm{Se}$ & $\mathrm{ppb}$ & 0.38 \\
\hline $\mathrm{Ca}^{2+}$ & ppm & 18.0 & $\mathrm{Br}$ & $\mathrm{ppb}$ & 47 \\
\hline$\overline{\mathrm{Mg}^{2+}}$ & $\mathrm{ppm}$ & 5.6 & $\mathrm{Rb}$ & $\mathrm{ppb}$ & 9.5 \\
\hline$\overline{\mathrm{Na}^{+}}$ & ppm & 35 & $\mathrm{Sr}$ & $\mathrm{ppb}$ & 100 \\
\hline $\mathrm{K}^{+}$ & $\mathrm{ppm}$ & 4.9 & Y & $\mathrm{ppb}$ & 0.0054 \\
\hline $\mathrm{HCO}_{3}^{-}$ & ppm & 180 & $\mathrm{Zr}$ & $\mathrm{ppb}$ & 0.011 \\
\hline $\mathrm{SO}_{4}^{2-}$ & ppm & 60 & $\mathrm{Nb}$ & $\mathrm{ppb}$ & $\begin{array}{c}<300 \mathrm{E}- \\
6\end{array}$ \\
\hline $\mathrm{H}_{2} \mathrm{~S}$ & ppm & 3.6 & Mo & $\mathrm{ppb}$ & 0.022 \\
\hline $\mathrm{Cl}^{-}$ & ppm & 13.5 & $\mathrm{Ag}$ & $\mathrm{ppb}$ & 0.04 \\
\hline $\mathrm{Si}$ & ppm & 85 & $\mathrm{Cd}$ & $\mathrm{ppb}$ & 0.003 \\
\hline TDS, calculated & ppm & 410 & Sn & $\mathrm{ppb}$ & 0.015 \\
\hline $\mathrm{Li}$ & $\mathrm{ppb}$ & 47 & $\mathrm{Sb}$ & $\mathrm{ppb}$ & 0.028 \\
\hline$B$ & $\mathrm{ppb}$ & 980 & $\mathrm{Te}$ & $\mathrm{ppb}$ & 0.006 \\
\hline $\mathrm{Be}$ & $\mathrm{ppb}$ & 0.015 & 1 & $\mathrm{ppb}$ & 6 \\
\hline $\mathrm{Al}$ & $\mathrm{ppb}$ & 33 & Cs & $\mathrm{ppb}$ & 2.4 \\
\hline$P$ & $\mathrm{ppb}$ & 160 & $\mathrm{Ba}$ & $\mathrm{ppb}$ & 98 \\
\hline $\mathrm{Zn}$ & $\mathrm{ppb}$ & 85 & $\mathrm{Ta}$ & $\mathrm{ppb}$ & $\begin{array}{c}<200 \mathrm{E}- \\
6\end{array}$ \\
\hline $\mathrm{Ti}$ & $\mathrm{ppb}$ & 0.75 & W & $\mathrm{ppb}$ & 0.083 \\
\hline V & $\mathrm{ppb}$ & 0.084 & $\operatorname{Re}$ & $\mathrm{ppb}$ & $\begin{array}{c}2.00 \mathrm{E}- \\
04\end{array}$ \\
\hline $\mathrm{Cr}$ & $\mathrm{ppb}$ & 0.11 & $\mathrm{Hg}$ & $\mathrm{ppb}$ & 0.8 \\
\hline $\mathrm{Mn}$ & $\mathrm{ppb}$ & 610 & $\mathrm{Tl}$ & $\mathrm{ppb}$ & 0.0011 \\
\hline $\mathrm{Fe}$ & $\mathrm{ppb}$ & 16 & $\mathrm{~Pb}$ & $\mathrm{ppb}$ & 0.13 \\
\hline $\mathrm{Co}$ & $\mathrm{ppb}$ & 0.054 & $\mathrm{Bi}$ & $\mathrm{ppb}$ & 0.0015 \\
\hline $\mathrm{Ni}$ & $\mathrm{ppb}$ & 0.17 & Th & $\mathrm{ppb}$ & $\begin{array}{c}<500 \mathrm{E}- \\
6 \\
\end{array}$ \\
\hline $\mathrm{Cu}$ & $\mathrm{ppb}$ & 0.4 & U & $\mathrm{ppb}$ & 0.0015 \\
\hline
\end{tabular}

that the mechanism of formation of high $\mathrm{Hg}$ content in Chloridnoye Lake is the same.

\section{Microbial communities}

A thin green cyanobacterial film living at $45-49^{\circ} \mathrm{C}$ is found along the edge of the crater. With the decrease in water temperature along the stream, this cyanobacterial community is replaced gradually by filamentous green algae (Table 3). Further downstream, a thin, green (up to $0.7 \mathrm{~cm})$, easily disintegrated community is present at $35^{\circ}$ $\mathrm{C}\left(30-40^{\circ} \mathrm{C}\right)$. A dark greenish-grey "bushy" community, consisting of thin fields, is found at $22^{\circ} \mathrm{C}$. Its appearance persists as temperatures decreased from 22 to $17^{\circ} \mathrm{C}$. Colonies of green soil algae develop here, not far from the spring, in water $\left(13^{\circ} \mathrm{C}\right)$-filled depressions made by humans and animals. In the crater itself, under thick layers of sulphur, orange-brown leathery organomineral mat-like structures, about $0.3 \mathrm{~cm}$ thick, are found. According to microscopic observations, this mat is formed by filamentous bacteria (Figures 4, 5).

\section{Composition of the bacterial community}

Bacteria of the type Caldiserica, which is also widely represented in thermal springs in Japan and Yellowstone (USA), are the most numerous in the studied community (34.8\%). The majority of these sequences have $99 \%$ sequence similarity to Caldisericum exile AZM16c01 (Figure 6). About $1.0 \%$ of sequences are not closely related to any cultured microorganisms. The representatives of this type are filamentous thermophiles and heterotrophs, with growth optima ranging from $60-75^{\circ} \mathrm{C}$, and $\mathrm{pH}$ optima ranging from 5.5-7.5 [21]. About $0.4 \%$ of sequences of this type are $98 \%$ similar to bacteria from hot springs in Papua New Guinea [22] and Yellowstone [23]. Most represented species of prokaryotes are show in Table 4

The next most abundant group contains sequences related to the Dictyoglomi type (25.5\%) These microorganisms are abundant in thermal habitats [24]. Almost all sequences are very similar or identical to the Dictyoglomus turgidum DSM 6724 strain, which was isolated from Kamchatka thermal springs [25]. These bacteria are filamentous obligate anaerobes and chemoorganotrophs; their optimal temperature is about $70^{\circ} \mathrm{C}$ and their $\mathrm{pH}$ optima range from 6.0-9.0 [26].

Bacteria of the Aquificae type are usually dominant in thermal waters with neutral $\mathrm{pH}$, and $12.7 \%$ of the sequences fall into this type. Members of the Aquificae are heterotrophs or chemolythotrophs, microaerophiles or obligate anaerobes [27]. About $11.3 \%$ of the sequences we analysed belong to the Sulfurihydrogenibium genus. One of the species of this genus, Sulfurihydrogenibium rodmanii is found in the Kamchatka hydrotherms [28]. Our sequences show 99\% sequence similarity to Sulfurihydrogenibium yellowstonense SS5 [29]. This species is a chemolithoautotroph and can oxidize sulphur in microaerophilic conditions. Another $1.3 \%$ of sequences belong to members of the Thermosulfidibacter genus, and have 98\% sequence similarity to Thermosulfidibacter takaii ABI70S6, which is an obligate anaerobe, a hydrogenoxidizing chemolithoautotroph and a sulphate reducer, with growth optimum at $70^{\circ} \mathrm{C}$ and $\mathrm{pH}$ optima ranging from 5.0-7.5 [30].

The Proteobacteria type in the Zavarzin community is represented by the Deltaproteobacteria, Betaproteobacteria and Gammaproteobacteria classes. $6.9 \%$ of the sequences are identical to Desulfurella kamchatkensis K-119 (Deltaproteobacteria), which was isolated from the Kamchatka thermal springs. Representatives of this 

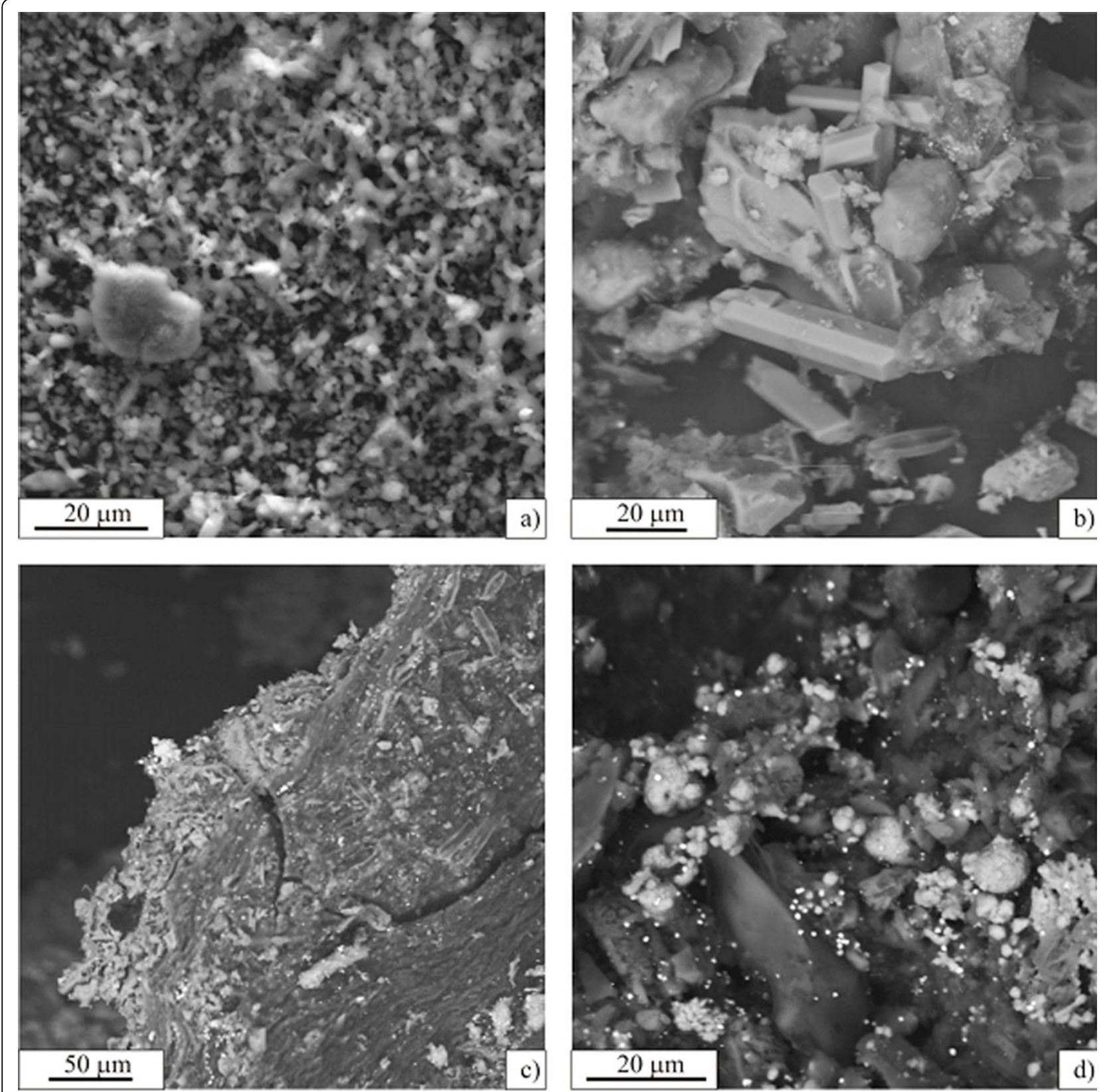

Figure 3 Mineral deposits of Zavarzin. (a) drop-like particles of native sulfur, a big opal formation is located in the center. (b) gypsum crystals among igneous rock detritus. (c) organomineral aggregate of the benthos microbial communities includes bacterial filaments, diatom shells, detritus of igneous rock from the Uzon caldera, sphere-like pyrite coalescences regions consolidated by opal, and submicron particles of mercury sulfide. (d) sphere-like pyrite coalescences and submicron particles of cinnabar cover the organomineral aggregate of the benthos community.

genus are obligate anaerobes, sulphate reducers, can live on media containing hydrogen and sulphur, and may act as heterotrophs, processing organic acids to $\mathrm{CO}^{2}$ and water. These bacteria have growth optima ranging from $50-70^{\circ} \mathrm{C}$ and $\mathrm{pH}$ optima ranging from 6.0-8.0 [31]. The remaining $0.6 \%$ have $96 \%$ sequence similarity to Syntrophorabdus aromaticivorans UI, which is an obligate anaerobe, can oxidize phenol, and has a growth optimum at $37^{\circ} \mathrm{C}$ and $\mathrm{pH}$ optima ranging from 6.0-7.0 [32].

Sequences belonging to the Nitrospirae type constitute $3.3 \%$ of all sequences; $1.2 \%$ are identical to Thermodesulfovibrio yellowstonii DSM 11347 [33]. The remaining $2.0 \%$ are $97 \%$ similar to a bacterium in thermal springs in Thailand [34], which is placed within the Nitrospirae, despite its low sequence similarity (78\%) to other 
Table 2 Elemental composition in bottom sediments and the benthos microbial community of Zavarzin

\begin{tabular}{|c|c|c|c|c|c|c|c|c|}
\hline $\begin{array}{l}\text { Elemental } \\
\text { composition }\end{array}$ & Units & $\begin{array}{l}\text { Sulfur bottom } \\
\text { sediments }\left(C_{s}\right)\end{array}$ & $\begin{array}{l}\text { Cyanobacterial community along } \\
\text { the edge of the gryphon }\end{array}$ & $\begin{array}{l}\text { Enclosing lake } \\
\text { deposits }\left(C_{L}\right)\end{array}$ & $\begin{array}{l}\text { Benthos } \\
\text { community } \\
\left(C_{c}\right)\end{array}$ & $\begin{array}{l}\mathrm{C}_{\mathrm{C}^{-}} \\
\mathrm{C}_{\mathrm{L}}\end{array}$ & $\begin{array}{l}\log \\
\left(C_{s} / C_{w}\right)\end{array}$ & $\begin{array}{l}\log \\
\left(C_{c} / C_{w}\right)\end{array}$ \\
\hline $\mathrm{Ca}$ & $\%$ & 0.15 & 0.2 & 1.7 & 1.4 & $\sim^{*}$ & 2 & - \\
\hline $\mathrm{Na}$ & $\%$ & 0.1 & 0.08 & 1.2 & 1.2 & $\sim$ & 1 & - \\
\hline $\mathrm{K}$ & $\%$ & 0.25 & 0.28 & 1.9 & 0.85 & $\sim$ & 3 & - \\
\hline SC & ppm & 1.8 & 1.4 & 17.0 & 17.1 & $\sim$ & n.d. & - \\
\hline $\mathrm{Ti}$ & $\%$ & 0.04 & 0.03 & 0.90 & 0.90 & $\sim$ & 6 & - \\
\hline $\mathrm{V}$ & ppm & $<0.05$ & $<0.05$ & 160 & 113 & $\sim$ & 3 & - \\
\hline $\mathrm{Cr}$ & ppm & $<3$ & $<2$ & 7.5 & 9 & $\sim$ & 4 & - \\
\hline$M n$ & ppm & 6 & 3 & 89 & 94 & $\sim$ & 2 & - \\
\hline $\mathrm{Fe}$ & $\%$ & 0.4 & 0.3 & 5.0 & 4.6 & $\sim$ & 5 & - \\
\hline $\mathrm{Co}$ & ppm & 1.3 & 0.9 & 13.5 & 13.3 & $\sim$ & 4 & - \\
\hline $\mathrm{Ni}$ & ppm & 10.0 & 7.5 & 11.5 & 12.2 & $\sim$ & 5 & - \\
\hline $\mathrm{Cu}$ & ppm & 17.7 & 19.2 & 24.5 & 38.0 & 13.5 & 5 & 5 \\
\hline $\mathrm{Zn}$ & ppm & 22.5 & 20.5 & 66.0 & 60.5 & $\sim$ & 2 & - \\
\hline $\mathrm{Ga}$ & ppm & 5.6 & 5.0 & 19.2 & 16.5 & $\sim$ & 5 & - \\
\hline $\mathrm{Ge}$ & ppm & $<0.05$ & $<0.05$ & 2.4 & $<0.05$ & $\sim$ & 2 & - \\
\hline As & ppm & 27 & 16 & 52 & 122 & 70 & 3 & 4 \\
\hline $\mathrm{Se}$ & ppm & $<0.05$ & $<0.05$ & $<0.05$ & 0.7 & 0.7 & 2 & 3 \\
\hline $\mathrm{Br}$ & ppm & 7.9 & 8.7 & 4.0 & 82.5 & 78.5 & 2 & 3 \\
\hline $\mathrm{Rb}$ & ppm & 0.4 & 0.5 & 21.5 & 9.5 & $\sim$ & 2 & - \\
\hline $\mathrm{Sr}$ & ppm & 13.5 & 10.6 & 280.0 & 154.0 & $\sim$ & 2 & - \\
\hline$Y$ & ppm & 3.2 & 2.4 & 22.6 & 25.0 & $\sim$ & 6 & - \\
\hline $\mathrm{Zr}$ & ppm & 17.0 & 10.3 & 141.5 & 154.5 & $\sim$ & 6 & - \\
\hline $\mathrm{Nb}$ & ppm & 0.4 & 0.5 & 3.4 & 3.2 & $\sim$ & 6 & - \\
\hline Mo & ppm & 0.25 & 0.28 & 1.40 & 1.45 & $\sim$ & 4 & - \\
\hline $\mathrm{Ag}$ & ppm & 0.42 & 0.35 & 0.30 & 0.30 & $\sim$ & 4 & - \\
\hline $\mathrm{Cd}$ & ppm & 0.20 & 0.40 & 0.70 & 0.45 & $\sim$ & 5 & - \\
\hline $\mathrm{Sn}$ & ppm & 0.55 & 1.15 & 1.50 & 1.90 & $\sim$ & 5 & - \\
\hline $\mathrm{Sb}$ & ppm & 3.4 & 0.4 & 1.4 & 3.0 & 1.6 & 5 & 5 \\
\hline $\mathrm{Te}$ & ppm & 0.34 & $<0.05$ & $<0.05$ & 0.27 & $\sim$ & 5 & - \\
\hline 1 & $\mathrm{ppm}$ & 0.34 & 0.32 & 0.93 & 0.20 & $\sim$ & 2 & - \\
\hline Cs & ppm & 0.4 & 0.2 & 1.3 & 1.55 & $\sim$ & 2 & - \\
\hline $\mathrm{Hg}$ & ppm & 190 & 163 & 20 & 1300 & 1280 & 5 & 6 \\
\hline $\mathrm{Pb}$ & ppm & 2.7 & 3.8 & 10.5 & 11.7 & $\sim$ & 4 & - \\
\hline Th & ppm & 0.3 & n.d. & 1.5 & 1.5 & $\sim$ & 6 & - \\
\hline U & ppm & 0.05 & 1.4 & 2.55 & 0.675 & $\sim$ & 5 & - \\
\hline
\end{tabular}

Table 3 Types of microbial communities found in Zavarzin

\begin{tabular}{lll}
\hline Type of community & Localization site, temperature & Composition of dominant microorganisms \\
\hline $\begin{array}{l}\text { Bottom scale brown organomineral } \\
\text { formation }\end{array}$ & Crater of Zavarzin, depth of $30-50 \mathrm{~cm} .56^{\circ} \mathrm{C}$ & Filamentous bacteria \\
\hline Thin green flowing single-layer films & Develop along the edge of Zavarzin. About $40^{\circ} \mathrm{C}$ & Filamentous cyanobacteria \\
\hline Loose thin dark green-gray epibioses & $\begin{array}{l}\text { Develop along the stream branching off from } \\
\text { Zavarzin, } 20^{\circ} \mathrm{C}\end{array}$ & $\begin{array}{l}\text { Filamentous cyanobacteria and filamentous green } \\
\text { algae }\end{array}$ \\
\hline Green epibioses/films on cold soil & Ubiquitous. $10-15^{\circ} \mathrm{C}$ & Unicellular and colonial green algae \\
\hline
\end{tabular}




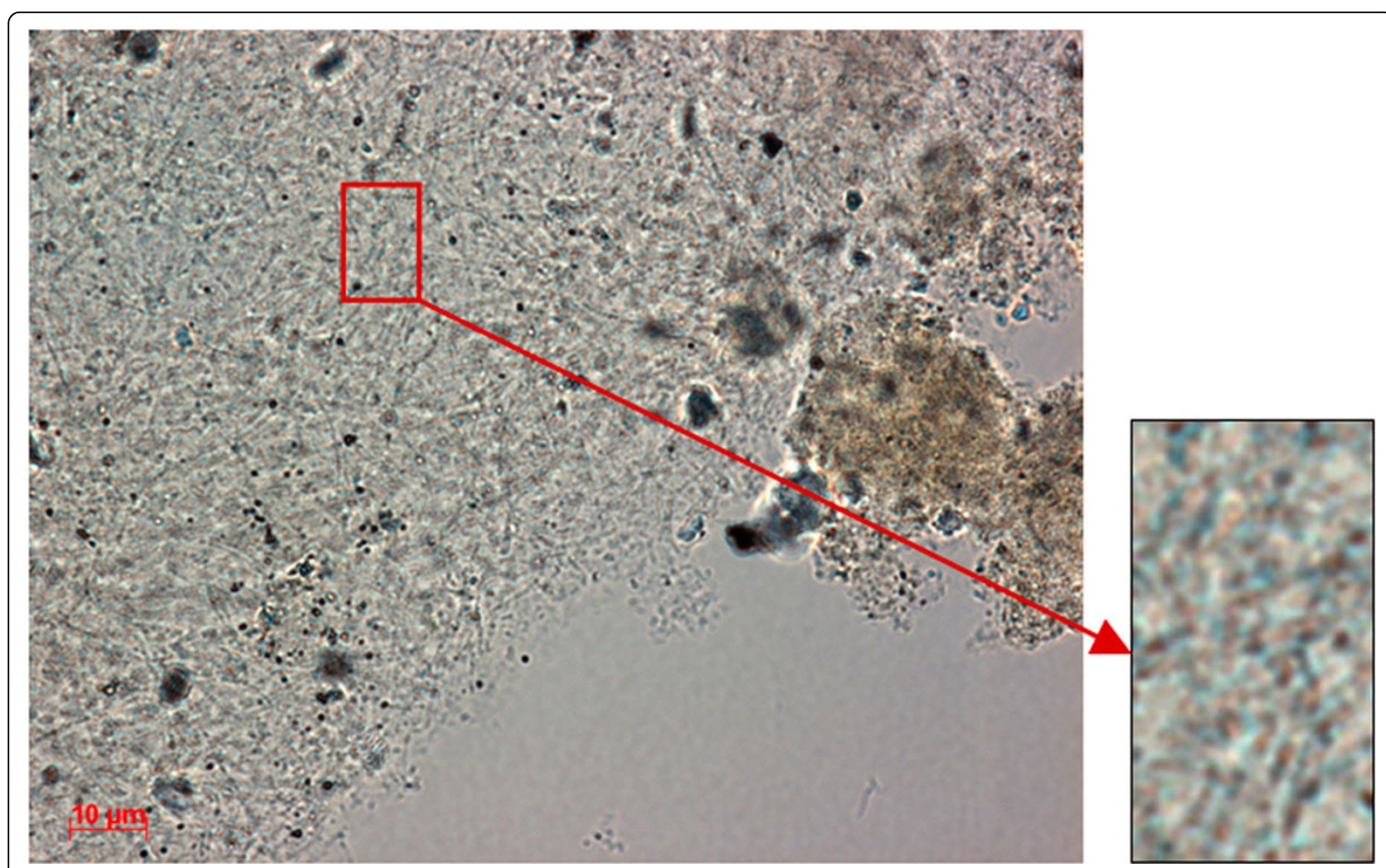

Figure 4 Dominant morphotypes of the Zavarzin benthos microbial community (location U-1-1). Transmitted light microscopy.

representatives of this type [35]. The sequence is $89 \%$ similar to an uncultured Dehalococcoides (Chloroflexi) [36] and $89 \%$ similar to other published sequences [37]. Therefore, its phylogenetic position requires further revision.

The Thermotogae type is represented by $2.0 \%$ of sequences, all of which are $99 \%$ similar to Fervidobacterium nodosum Rt17-B1, extracted from thermal springs in New Zealand [38,39]. This microorganism is an obligate anaerobe and a chemoheterotroph, which actively grows at 50-80 ${ }^{\circ} \mathrm{C}$ and $\mathrm{pH}$ 6.0-8.0.

Approximately $1.5 \%$ of the sequences belong to the Firmicutes type and have $93 \%$ to $98 \%$ similarity to
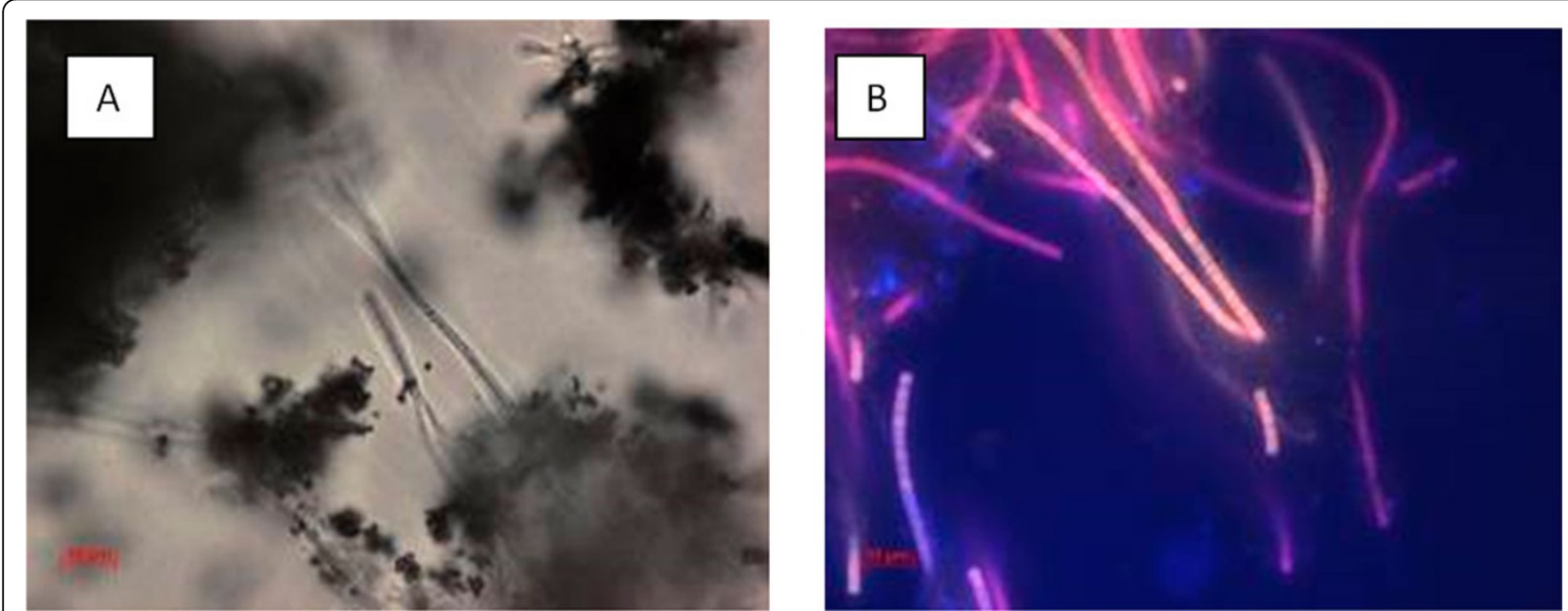

Figure 5 Morphology of the dominant microorganisms of Zavarzin community (location U-1-2). Microscopy A, transmitted light B, fluorescence. 


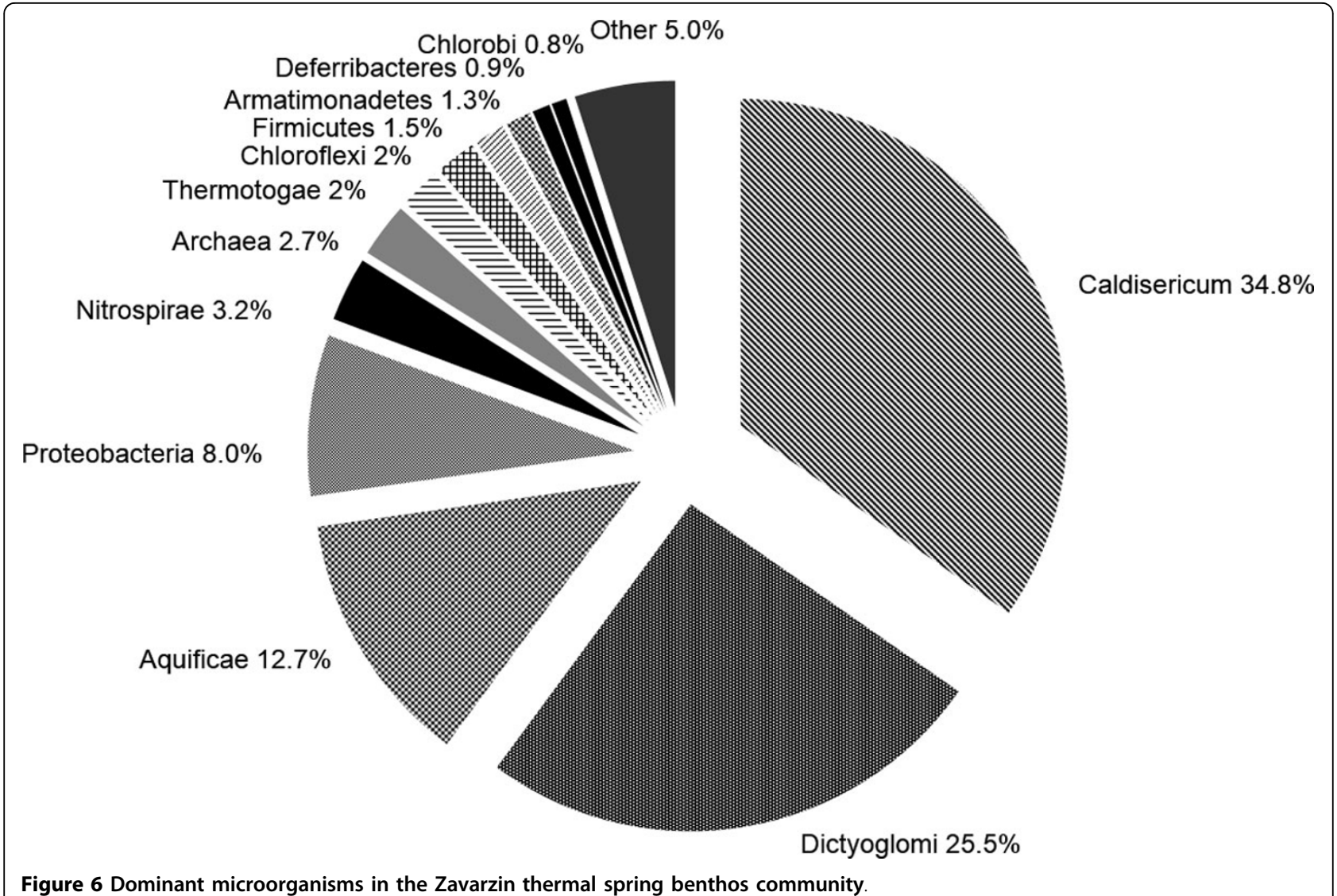

representatives of the Clostridia class (1.4\%). Half are 94\% similar to Clostridium cellulosi, which is an obligate anaerobe and a heterotroph, with a growth optimum at neutral $\mathrm{pH}$ and $55-60^{\circ} \mathrm{C}[40]$. About $0.1 \%$ of the sequences have 93\% sequence similarity to Eubacterium sp. from Yellowstone cyanobacterial mats [41]. Another $0.1 \%$ is $98 \%$ similar to Clostridium symbiosum, and the remaining 95\% are similar to Desulfotomaculum geothermicum DSM 3669, which is an obligate anaerobe, a heterotroph and a hydrogen-oxidizing, sulphate reducer [42].

About $1.2 \%$ of all sequences belong to the Thermodesulfobacteria type. All are $99 \%$ similar to Caldimicrobium rimae DS, an obligate anaerobe, a facultative autolithotroph, which can grow in the presence of hydrogen and thiosulfate, using $\mathrm{CO}^{2}$ as a carbon source; it's growth optimum is at $\mathrm{pH} 6.8-7.5$ and $52-82^{\circ} \mathrm{C}$ [43].

Another $0.1 \%$ of sequences have sequence similarity to bacteria of the Actinobacteria type. They have 94\% sequence similarity to uncultured, rhizospheric Gaiella occulta F2-233 [44] and are not closely related to any cultured thermophilic microorganism.

About $1.4 \%$ of our sequences had $93-100 \%$ sequence similarity to the following candidate types: AC1, OP1 and OD1. Our sequences falling into OP1 are closely related to those from Uzon [17] and Central Tibet [45].
Representatives of the Armatimonadetes (1.3\%) are closely related (99\%) to the uncultured bacteria found in Uzon [17], Yellowstone [8] and Central Tibet [45].

Approximately $2.6 \%$ of our sequences are not closely related to culturable microorganisms, but are $>99 \%$ similar to the sequences obtained from environmental samples from the Uzon caldera [17].

Representatives of the Deferribacteres type make up $0.8 \%$ of our sequences. They are $99 \%$ similar to Calditerrivibrio nitroreducens DSM 19672 from thermal springs in Japan, which is an obligate anaerobe, a heterotrophic nitrate reducer that reduces nitrate to ammonium, and which has a growth optimum of $55^{\circ} \mathrm{C}$ and $\mathrm{pH}$ 7.0-7.5 [46].

Chloroflexi accounted for less than $2 \%$ of all sequences. Half of these were highly similar to Chloroflexus aurantiacus J-10-fl from Japanese hot springs, a photosynthetic autotroph that can also grow heterotrophically in darkness at $52-60^{\circ} \mathrm{C}$ and $\mathrm{pH} 8.0$.

\section{Archaeal community}

About $2.7 \%$ of the obtained sequences fall into the Archaea domain. Representatives of Crenarchaeota (37\%), Euryarchaeota (3.7\%), and Thaumarchaeota (59\%) were found. Euryarchaeota-related sequences are 
Table 4 Microbial community of the Zavarzin benthos mat

\begin{tabular}{|c|c|c|c|c|}
\hline Domain & Phylum & $\begin{array}{l}\% \text { of the total sequence } \\
\text { set }\end{array}$ & Most closely related $16 \mathrm{~S}$ sequence & $\begin{array}{l}\text { Sequence similarity } \\
(\%)\end{array}$ \\
\hline \multirow[t]{18}{*}{ Bacteria } & Caldiserica & 33.4 & Caldisericum exile AZM16c01 & 98 \\
\hline & & 1.0 & Uncultured bacterium clone ZB_P11_J22 & 99 \\
\hline & & 0.4 & Uncultured bacterium clone OPB14 & 98 \\
\hline & Dictyoglomi & 25.5 & Dictyoglomus turgidum DSM 6724 & 99 \\
\hline & Aquificae & 11.3 & Sulfurihydrogenibium yellowstonense strain SS5 & 99 \\
\hline & & 1.3 & Thermosulfidibacter takaii strain ABI70S6 & 98 \\
\hline & & 0.8 & Uncultured Aquificales bacterium clone YNP_SBC_QL1_B3 & 89 \\
\hline & Deltaproteobacteria* & 6.0 & Desulfurella kamchatkensis K-119 & 100 \\
\hline & & 1.3 & Syntrophorhabdus aromaticivorans UI & 96 \\
\hline & Nitrospirae & 1.2 & Thermodesulfovibrio yellowstonii DSM 11347 & 100 \\
\hline & & 2.0 & Uncultured Nitrospirae bacterium clone OTU74 & 96 \\
\hline & Thermotogae & 2.0 & Fervidobacterium nodosum Rt17-B1 & 99 \\
\hline & $\begin{array}{l}\text { Bacteroidetes/ } \\
\text { Chlorobi }\end{array}$ & 0.1 & $\begin{array}{l}\text { Chitinophagaceae bacterium enrichment culture clone } \\
\text { NB-10 }\end{array}$ & 97 \\
\hline & & 0.4 & $\begin{array}{l}\text { Chlorobi bacterium enrichment culture clone phylotype } \\
\text { P1 }\end{array}$ & 97 \\
\hline & & 0.7 & Uncultured Chlorobium sp. clone OPPB063 & 94 \\
\hline & Thermodesulfobacteria & 1.2 & Caldimicrobium rimae strain DS $16 \mathrm{~S}$ & 99 \\
\hline & Candidate divisions & 1.1 & Candidate division clone & - \\
\hline & Other & 6.0 & & \\
\hline \multirow[t]{6}{*}{ Archaea } & Crenarchaeota & 0.4 & Uncultured Crenarchaeota 16S rRNA gene, clone C10 & 95 \\
\hline & & 0.3 & Uncultured crenarchaeote clone A14-32 & 95 \\
\hline & & 0.2 & Uncultured crenarchaeote clone A14-45 & 96 \\
\hline & Thaumarchaeota & 1.6 & Uncultured thaumarchaeote clone 8_Kam37 & 96 \\
\hline & Euryarchaeota & 0.1 & Uncultured archaeon clone ZA_P5_B12 & 97 \\
\hline & & 0.3 & Uncultured archaeon $16 \mathrm{~S}$ rRNA gene, clone N8-H5 & 93 \\
\hline
\end{tabular}

97\% similar to those of the uncultured microorganisms obtained from the Uzon caldera [47]. Sequences belonging to the Crenarchaeota were closely related to those from the Uzon caldera obtained by other authors, and less similar (95\%) to those from thermal springs in Bulgaria [48], Mexico [49] and China [50]. Thaumarchaeota-like sequences were $96 \%$ similar to the sequences of the archaea found in the Kamchatka thermal springs [51,52].

\section{Metabolism of the benthic microbial community}

In this study, we obtained information on the structure and composition of the benthic microbial community in the Zavarzin spring. Given the high degree of sequence similarity that was characteristic of most obtained sequences, assumptions regarding the metabolic pathways characteristic of the community and its interactions with the water microbial community appear reasonable.

Gumerov et al. [16] have suggested that the primary production of organic substances in Zavarzin may be formed both by photosynthesis and chemolithoautotrophy. Chloroflexi (2.0\%) and chemolithotrophs (about 15\%) account for significantly smaller numbers of sequences in comparison with the water and cyanobacterial mats of Zavarzin. It was demonstrated that chemolithooautotrophic production may be performed by the following groups: the Aquificae (Sulfurihydrogenibium yellowstonense SS5, 11.3\%, and Thermosulfidibacter takaii, 1.3\%) and the Thermodesulfobacteria (Caldimicrobium rimae DS, $1.2 \%)[33,34,49]$. It is evident that the main production of organic substances in Zavarzin takes place in the water and the cyanobacterial mat. However, Burgess et al. [17], who searched for primary producers in an integral sample from Zavarzin, did not find any primary producers, suggesting that this ecosystem depends on an allochthonous carbon source.

Most sequences that we obtained from the benthic mat belong to decomposers of organic substances. These are organotrophs that form the structure of the community. Over $50 \%$ of the sequences belong to the Caldiserica (34.8\%) and Dictyoglomi (25.5\%), while Proteobacteria, Thermotogae, Firmicutes and Deferribacteres are less abundant. Decomposition of organic substances may be achieved either by fermentation or by complete oxidation 
using oxygen, nitrate, sulphur or thiosulfate as electron acceptors. Most microorganisms from the benthic mat use sulphur, which is formed by the oxidation of hydrogen sulphide in the water, as an electron acceptor. No organisms capable of nitrification were found in the water of Zavarzin. However, they were found in the benthic mat: Archaea belonging to the Thaumarchaeota type (1.6\%) and bacteria belonging to the Nitrospirae (3.3\%).

Thus, the decomposition of the organic substances that are produced in the water in the cyanobacterial mat is the major process that takes place in the benthic microbial mat.

A comparison of the microbial communities in water, benthos, and the integral sample

In their work [17] concerned with thermal ecosystems of the Uzon caldera, Burgess et al [17] used cloning to determine the microbial composition in a Zavarzin thermal spring integral sample. Two previous studies [16,17], and our current study, are based on pyrosequencing, allowing direct comparisons of microbial communities in the water and the benthic mat of the Zavarzin thermal spring.

Microbial communities of the benthos and water of Zavarzin are similar in composition, but have considerable quantitative differences, as the dominant microorganisms clearly demonstrate (Table 5), that is, the representatives of the Caldiserica and Dictyoglomi, which are able to form a hard matrix and the structure of the benthic mat, are only weakly represented in the water. Representatives of the Aquificae, which are dominant in surface hydrothermals at hyperthermophilic temperatures, are prevalent in the water, but less abundant in the benthic mat.
Other microorganisms that are dominant in the water sample are either absent or scarce in the benthic mat. The Proteobacteria type is widely represented in the water (Alpha-, Beta-, Gamma- and Epsilonproteobacteria), while only Deltaproteobacteria are abundant in the benthic mat.

Thermotogae, Thermodesulfobacteria and Deferribacteres are also less abundant in the benthic mat. No representatives of Deinococcus-Thermus, Verrucomicrobia and Cyanobacteria, as well as no archaea belonging to the Korarchaeota and Nanoarchaeota, are found in the benthos mat.

Candidate types represent $0.3 \%$ to $6 \%$ of this community, but only one type (BRC1) was found in the water; this type belongs to soil and rhizosphere microorganisms that were probably transferred from nearby locations to the soil of Zavarzin. In addition, no representatives of Nitrospirae and Thaumarchaeota are found in the water.

A phylogenetic clade endemic to Zavarzin was detected in the water and in the integral sample. This clade is present in the benthic mat as well: sequences that have no sequence similarity to cultured microorganisms, but are closely related (>99\%) to the sequences from the study of Burgess et al [17].

\section{Conclusions}

Pyrosequencing of the benthic mat of Zavarzin allowed us to study the composition and structure of microbial communities of Zavarzin, the distribution of some of its components, as well as some of their functional characteristics. The Zavarzin community is a full-fledged trophic system containing various phylogenetic groups of microorganisms, including some potentially new ones.

Table 5 Composition of the microbial communities in water, integral sample, and benthos mat in Zavarzin thermal spring

\begin{tabular}{|c|c|c|c|c|}
\hline Domain & Phylum & $\%$ in benthos mat & $\%$ in water sample & $\%$ in integral sample ** \\
\hline \multirow[t]{15}{*}{ Bacteria } & Caldiserica & 34.8 & 1.72 & 1 \\
\hline & Dictyoglomi & 25.5 & 1.65 & 2 \\
\hline & Aquificae & 12.7 & 32.27 & 3 \\
\hline & Proteobacteria & 8.0 & 23 & 13 \\
\hline & Alphaproteobacteria* & - & $>1$ & - \\
\hline & Deltaproteobacteria* & 7.3 & 3.01 & - \\
\hline & Betaproteobacteria* & 0.3 & 6.57 & 13 \\
\hline & Gammaproteobacteria* & 0.4 & 10.99 & - \\
\hline & Epsilonproteobacteria* & - & $>1$ & - \\
\hline & Nitrospirae & 3.2 & - & 3 \\
\hline & Thermotogae & 2.0 & 6.27 & - \\
\hline & Firmicutes & 1.5 & $>1$ & 0.3 \\
\hline & Thermodesulfobacteria & 1.2 & 6.32 & - \\
\hline & Bacteroidetes/Chlorobi & 0.8 & $>1$ & - \\
\hline & Actinobacteria & 0.1 & $>1$ & - \\
\hline
\end{tabular}


Table 5 Composition of the microbial communities in water, integral sample, and benthos mat in Zavarzin thermal spring (Continued)

\begin{tabular}{|c|c|c|c|c|}
\hline & Chloroflexi & 2.0 & $>1$ & 38 \\
\hline & Deferribacteres & 0.9 & 12.15 & 8 \\
\hline & Armatimonadetes & 1.3 & - & 6 \\
\hline & Candidate divisions AC1, OP1, OD1 & 1.4 & - & - \\
\hline & Acidobacteria & 0.3 & $>1$ & 1 \\
\hline & Deinococcus-Thermus & - & 4.35 & - \\
\hline & Verrucomicrobia & - & 1.01 & - \\
\hline & Candidate division BRC1 & 0.1 & 1.70 & 0.3 \\
\hline & Cyanobacteria & - & $>0.20$ & - \\
\hline & New lineage 1 & - & 1.04 & + \\
\hline & New lineage 2 & - & - & - \\
\hline & Unclassified & 3.8 & - & 24 \\
\hline \multirow[t]{6}{*}{ Archaea } & Crenarchaeota & 1.0 & 2.25 & 59 \\
\hline & Thaumarchaeota & 1.6 & - & - \\
\hline & Euryarchaeota & 0.1 & 1.89 & 7 \\
\hline & Korarchaeota & - & 0.34 & 21 \\
\hline & Nanoarchaeota & - & 0.02 & - \\
\hline & Unclassified & - & - & 13 \\
\hline
\end{tabular}

${ }^{*}$ class

** \% of bacterial (300) and archaeal (91) sequences

+ this group was found in the integral sample, but the percentage of clones was not specified

Geochemistry dramatically influences the structure and metabolism of microbial communities, as both are directly associated with the environment and depend on strict conditions. Therefore, in contrast to the water of the spring, only sessile microorganisms with particular metabolism types, adapted to strict anaerobic conditions and able to live on certain substrates can inhabit the benthic microbial mat of Zavarzin.

Geothermal systems that exist in areas of recent volcanism are characterized by common geochemical parameters, e.g., high temperature, lack of oxygen, presence of sulphides and many rare and trace metals, etc. However, despite extreme conditions, these ecosystems harbour a great diversity of microorganisms [53]. The fact that DNA sequences belonging to microorganisms of various taxa, including new phylogenetic groups, have been found in Zavarzin, and other extreme ecosystems as well, indicates that the microbial population of our planet is insufficiently studied, and suggests that extensive speciation may take place in areas of recent volcanism.

It is noteworthy that some elements accumulated in this benthic community, such as $\mathrm{Br}$ and Se, are enriched by three orders of magnitude in comparison with the water of this spring, while others, such $\mathrm{As}, \mathrm{Cu}$ and $\mathrm{Sb}$, and $\mathrm{Hg}$, are enriched by four, five, and six orders of magnitude, respectively. These elements may be adsorbed either actively or passively with subsequent fixation as sulphide minerals. This fact may dramatically influence the composition and structure of the community, and may also enhance the potential mutagenic effects of some of these elements.

A multitude of new microorganisms, including those having unique metabolic pathways, have recently been described, and many biotechnologically important genes and enzymes have been cloned [54]. With this in mind, it is hoped that this ecosystem will continue to give insights into microbial biodiversity. However, studying these ecosystems remains important for biodiversity, conservation and biotechnology. We are planning further studies of various hydrothermal outlets in Kamchatka.

\section{Methods}

\section{Sampling and microscopy}

Mat pieces were collected using a sterile sampler and placed into sterile containers and stored at $4{ }^{\circ} \mathrm{C}$. Some samples were fixed using $4 \%$ formalin or $50 \%$ ethanol. Mat samples were studied using light and fluorescence microscopy (Axioskop A1; Axioimager Z1, Carl Zeiss, Germany) in the Microscopy Centre (IC\&G SB RAS, Novosibirsk).

\section{Chemical analysis of water and the benthic mat}

Unstable water parameters were analysed in situ: $\mathrm{O}_{2}$ content (commercial test, Merck, Germany) and $\mathrm{pH}$ and Eh ("Anion 4100" calibrated using standard solutions). The basic absolute error of $\mathrm{pH}$ measurement was \pm 0.1 . Temperature was determined using an electronic thermometer. 
Water was filtered through a $0.45-\mu \mathrm{m}$ membrane filter, and $2 \mathrm{ml}$ of distilled $\mathrm{HNO}_{3}$ were added per $0.5 \mathrm{l}$ of water for metal content analysis. Samples for basic ion content measurements were kept without preservation.

Water composition and trace element concentrations were determined using a set of methods that enabled cross-checking of the results. Atomic emission spectrometry with inductively coupled plasma (ICP-AS) (Optima 4300 DV), capillary electrophoresis, ICP-MS, and atomic absorption methods were used. Inorganic and organic carbon in solutions were measured using a Total Organic Carbon Analyzer, TOC-VCSH (Shumadzu, Japan). Mercury content was determined using atomic absorption spectrometry by the cold steam method (analyst Zh.O. Badmaeva).

The samples of the microbial community and bottom sediments were analysed via the SR-XRF method $(\mathrm{K}, \mathrm{Ca}$, $\mathrm{Ti}, \mathrm{V}, \mathrm{Cr}, \mathrm{Mn}, \mathrm{Fe}, \mathrm{Ni}, \mathrm{Cu}, \mathrm{Zn}, \mathrm{Ga}, \mathrm{Ge}, \mathrm{Se}, \mathrm{Br}, \mathrm{Rb}, \mathrm{Sr}, \mathrm{Y}$, $\mathrm{Zr}, \mathrm{Nb}, \mathrm{Mo}, \mathrm{Ag}, \mathrm{Cd}, \mathrm{Sn}, \mathrm{Sb}, \mathrm{Te}, \mathrm{Cs}, \mathrm{As}, \mathrm{Pb}, \mathrm{Th}$ and $\mathrm{U})$.

The SR-XRF method was used at the element analysis station VEPP-3 at the synchrotron emission Siberian Centre of the Nuclear Physics Institute SB RAS. An energydispersive X-ray optical SR-XRF scheme was applied in two modes of the primary monochromatic emission, 23 and $36 \mathrm{KeV}$ [55]. Processing of the spectra was conducted using the program AXIL. The contents of the elements were calculated using standard samples: BIL-1 (Baikal silt), 1633A (fly ash, National Bureau of Standards, USA), soil-7 (IAEA standard). For determining some of the elements, the instrumental neutron activation method was used.

The LEO 1430VP scanning electron microscope was used to examine the micromorphology and to determine the contents of minerals formed in the microbial communities.

\section{PCR amplification of metagenomic DNA}

Metagenomic DNA extracted from the Zavarzin benthic microbial community was used as a template for amplification of bacterial $16 \mathrm{~S}$ rRNA genes with universal primers: U341F (5'-CCTACGGGRSGCAGCAG-3', where R is A or $\mathrm{G}, \mathrm{S}$ is $\mathrm{G}$ or $\mathrm{C}$ ) and U515R (5'-TTTCCGCGGCK GCTGVCAC-3', where $\mathrm{K}$ is $\mathrm{G}$ or $\mathrm{R}, \mathrm{R}$ is $\mathrm{A}$ or $\mathrm{G}, \mathrm{V}$ is $\mathrm{A}$, $\mathrm{G}$, or C). Reagents for PCR (DMSO, PCR buffer, polymerase, nucleotide triphosphates) were products of Agilent Technologies, USA. $50 \mu \mathrm{l}$ of PCR mix contained $1 \times$ Herculase buffer, $10 \mu \mathrm{M}$ of each dNTPs, 10 pmoles of forward and reverse primers, $100 \mathrm{ng}$ of DNA, and $2.5 \mathrm{u}$ of Herculase. The following amplification profile was used: $3 \mathrm{~min}$ at $95^{\circ} \mathrm{C} ; 6$ cycles of $15 \mathrm{~s}$ at $95^{\circ} \mathrm{C}, 15 \mathrm{~s}$ at $50^{\circ} \mathrm{C}$, and $30 \mathrm{~s}$ at $72^{\circ} \mathrm{C} ; 35$ cycles of $10 \mathrm{~s}$ at $95^{\circ} \mathrm{C}, 10 \mathrm{~s}$ at $55^{\circ} \mathrm{C}$, and $30 \mathrm{~s}$ at $72^{\circ} \mathrm{C}$; and an additional elongation phase of $5 \mathrm{~min}$ at $72^{\circ} \mathrm{C}$. Amplified products were purified using commercial kits (Fermentas, Lithuania) and used for an additional PCR reaction with primers containing marker sequences that were designed for the "One-Way Reads" sequencing protocol, according to the manufacturer's instructions (Roche, Switzerland). Reamplification was performed using the same profile as for the initial amplification. The obtained PCR fragments were purified by electrophoresis in $1 \%$ agarose gels.

\section{Pyrosequencing}

Pyrosequencing of the variable V3 region of the $16 \mathrm{~S}$ rRNA gene was performed on a GS Junior System sequencer (Roche) using the "ONE-WAY READS AMPLICON SEQUENCING" protocol at the Engelhardt Institute of Molecular Biology RAS by Dr. A.V. Kudriavtseva.

\section{Sequence analysis}

A preliminary, quality filtering of 847 short nucleotide sequences (reads) was done with the PRINSEQ tool [56]. Then, 16S rRNA gene sequence reads with a mean length of about $187 \mathrm{bp}$ were filtered, de-noised and processed by the QIIME software package [57] using the USEARCH sequence analysis tool [58] implemented into the QIIME. The pipeline, including 11 steps, was performed. In the first step, sequences were sorted by length. In the second step, sequences were de-replicated, and the output file had unique sequences only, where each sequence description contained information regarding how many sequences exactly matched the sequence in question. In the third step, de-replicated sequences were sorted by abundance using the information from step 2 . In the forth step, sequences were clustered at $97 \%$ identity. In the fifth step, de-novo chimera checking using UCHIME [59] was performed. In the sixth step, reference-based chimera checking against the Gold database (http:// drive5.com/uchime/gold.fa) was made. In the next two steps, sequences tagged as non-chimeric during steps 6 and 7 were combined and sorted by abundance, and clusters with less than four reads were discarded. In the last three steps, an operational taxonomic units (OTU) picking, with an identity level greater than 0.80 , was performed; each non-chimeric read was assigned to the specific OTU identifier to which it belongs. In summation, 834 reads were clustered into 144 OTUs. The representative sequence for each OTU was queried against the GREENGENES database [60] with a make_otu_table.py script from QIIME.

\section{Competing interests}

The authors declare no potential conflict of interest with respect to financial or non-financial competing interests, the authorship and/or publication of this article.

\section{Authors' contributions}

AVB, EVL, OPT and SMZ collected the samples. AVB performed the

microscopy. EVL and OPT performed chemical and hydrogeological analyses. TKM and ASR extracted the DNA and processed samples for sequencing, TVI 
and VAI performed computational and statistical analyses. ASR and IAM planned the sequencing experiment. ASR, AVB and SEP wrote the manuscript, and all authors edited and commented on the paper. SME and NAK planned the expedition.

\section{Acknowledgements}

We are grateful to G.A. Karpov and the staff of the Kronotsky State Natural Reserve for their assistance in the organization of field studies in the Uzon caldera.

This work was financially supported in part by the SB RAS integration projects 92, 93 and 94, Budget Project VI.58.1.3 and RFBR grant 11-05-00717 (financial support of expedition and all the experimental work performed by AVB, EVL, OPT, SMZ, TKM, IAM, ASR, SME and SEP); Russian Science Foundation grant No 14-24-00123 (financial support of all the bioinformatics and statistics analysis performed by TVI and VAI).

\section{Declarations}

Publication of this article has been funded by the Russian Science Foundation grant No 14-24-00123.

This article has been published as part of BMC Genomics Volume 15 Supplement 12, 2014: Selected articles from the IX International Conference on the Bioinformatics of Genome Regulation and StructurelSystems Biology (BGRSISB-2014): Genomics. The full contents of the supplement are available online at http://www.biomedcentral.com/bmcgenomics/supplements/15/S12.

\section{Authors' details}

${ }^{1}$ Institute of Cytology \& Genetics SB RAS, Novosibirsk, 630090, Russia. ${ }^{2}$ V S Sobolev Institute of Geology and Mineralogy SB RAS, Novosibirsk, 630090 , Russia. ${ }^{3}$ Boreskov Institute of Catalysis SB RAS, Novosibirsk, 630090, Russia. ${ }^{4}$ Novosibirsk State University, Novosibirsk, 630090, Russia.

\section{Published: 19 December 2014}

\section{References}

1. Huber R, Huber H, Stetter K: Towards the ecology of hyperthermophiles: Biotopes, new isolation strategies and novel metabolic properties. FEMS Microbiol Rev 2000, 24:615-623.

2. Robb F, Antranikian G, Grogan D, Driessen A: Thermophiles: biology and technology at high temperatures Boca Raton: CRC Press; 2008.

3. Burra PV, Kalmar L, Tompa P: Reduction in Structural Disorder and Functional Complexity in the Thermal Adaptation of Prokaryotes. PLOS ONE 2010, 5:e12069.

4. Youssef NH, Couger MB, Elshahed MS: Fine-Scale Bacterial Beta Diversity within a Complex Ecosystem (Zodletone Spring, OK, USA): The Role of the Rare Biosphere. PLOS ONE 2010, 5:e12414.

5. Brock TD: Thermophilic microorganisms and life at high temperatures New York: Springer-Verlag; 1978

6. Bonch-Osmolovskaia EA: Studies of thermophilic microorganisms at the Institute of Microbiology, Russian Academy of Sciences. Mikrobiologiia 2004, 73:644-658.

7. Barns SM, Fundyga RE, Jeffries MW, Pace NR: Remarkable archaeal diversity detected in a Yellowstone National Park hot spring environment. Proc Natl Acad Sci USA 1994, 91:1609-1613.

8. Hugenholtz P, Pitulle C, Hershberger KL, Pace NR: Novel division level bacterial diversity in a Yellowstone hot spring. J Bacterio/ 1998, 180:366-376.

9. Kuznetsov SI: Microorganisms of hot springs of Kamchatka. Tr Latv Padomju Soc Repub Zinat Akad Mikrobiol Inst 1995, 4:130-154.

10. Zavarzin GA: Microbial diversity studies at the Winogradsky Institute of Microbiology. Mikrobiologiia 2004, 73:598-612.

11. Slepova TV, Sokolova TG, Lysenko AM, Tourova TP, Kolganova TV, Kamzolkina OV, Karpov GA, Bonch-Osmolovskaya EA: Carboxydocella sporoproducens sp. nov., a novel anaerobic CO-utilizing/H2-producing thermophilic bacterium from a Kamchatka hot spring. Int J Syst Evol Microbiol 2006, 56:797-800.

12. Galchenko VF, Barinova ES, Podosokorskaya OA, Akimov VN: Bacterial communities of Uzon caldera hydrotherms (Kamchatka). International Conference «Microorganisms and biosphere», november 19th - 20th, Moskow 25-26.

13. Chernyh NA, Perevalova AA, Slepova TV, Slobodkina GB, BonchOsmolovskaia EA: Phylogenetic analysis of natural microbial communities and enrichment culturesfrom hydrotherms of Uzon caldera. International Conference "Microorganisms and biosphere», november 19th - 20th, Moskow 2007, 145-146.

14. Kublanov IV, Perevalova AA, Slobodkina GB, Lebedinsky AV, Bidzhieva SK, Kolganova TV, Kaliberda EN, Rumsh LD, Haertlé T, Bonch-Osmolovskaya EA: Biodiversity of Thermophilic Prokaryoteswith Hydrolytic Activities in Hot Springs of Uzon Caldera, Kamchatka (Russia). Appl Environ Microbiol 2009, 75:286.

15. Mardanov AV, Gumerov VM, Beletsky AV, Perevalova AA, Karpov GA, BonchOsmolovskaya EA, Ravin NV: Uncultured archaea dominate in the thermal groundwater of Uzon Caldera, Kamchatka. Extremophiles 2011, 15:365-372.

16. Gumerov VM, Mardanov AV, Beletsky AV, Bonch-Osmolovskaia EA, Ravin NV: Molecular analysis of microbial diversity in the Zavarzin Spring, the Uzon caldera. Mikrobiologia 2011, 80:258-265.

17. Burgess EA, Unrine JM, Mills GL, Romanek CS, Wiegel J: Comparative geochemical and microbiological characterization of two thermal pools in the Uzon Caldera, Kamchatka, Russia. Microb Ecol 2012, 63:471-489.

18. Byhckov AYu: A geochemical model of current ore formation in Uzon caldera (Kamchatka). Moskow: GEOS 2009.

19. Naboko SI: Volcanism, hydrothermal processes, and ore formation. Moskow: Nedra 1974.

20. Migdisov AA, Bychkov AY: The behaviour of metals and sulphur during the formation of hydrothermal mercury-antimony-arsenic mineralization, Uzon caldera, Kamchatka, Russia. J Volcanol Geotherm Res 1998, 84:153-171.

21. Mori K, Yamaguchi K, Sakiyama Y, Urabe T, Suzuki K: Caldisericum exile gen. nov., sp. nov., an anaerobic, thermophilic, filamentous bacterium of a novel bacterial phylum, Caldiserica phyl. nov., originally called the candidate phylum OP5, and description of Caldisericaceae fam. nov., Caldisericales ord. nov. and Caldisericia classis nov. Int I Syst Evol Microbiol 2009, 59:2894-2898.

22. Amend J-P, Burcea L-C, Meyer-Dombard D-R: Microbial diversity in alkaline hot springs of Ambitle Island, Papua New Guinea. GenBank Database 2011 [http://www.ncbi.nlm.nih.gov/nuccore/JF935228.1].

23. Meyer-Dombard DR, Swingley W, Raymond J, Havig J, Shock EL, Summons RE: Hydrothermal ecotones and streamer biofilm communities in the Lower Geyser Basin, Yellowstone National Park. Environ Microbiol 2011, 13:2216-2231.

24. Saiki T, Kobayashi Y, Kawagoe K, Beppu T: Dictyoglomus thermophilum gen. nov., sp. nov., a Chemoorganotrophic, Anaerobic, Thermophilic Bacterium. Int I Syst Bacteriol 1985, 35:253-259.

25. Svetlichny VA, Svetlichnya TP: Dictyoglomus turgidus, sp. nov., a new extreme thermophilic eubacterium isolated from hot springs in the Uzon Volcano crater. Mikrobiologiia 1988, 57:435-441.

26. Krieg NR, Staley JT, Brown DR, Hedlund BP, Paster JB, Ward NL, Ludwig W, Whitman WB: Bergey's Manual of Systematic Bacteriology New York: Springer; 2010.

27. Spear JR, Walker JJ, McCollom TM, Pace NR: Hydrogen and bioenergetics in the Yellowstone geothermal ecosystem. Proc Natl Acad Sci USA 2005, 102:2555-2560.

28. O'Neill AH, Liu Y, Ferrera I, Beveridge TJ, Reysenbach AL: Sulfurihydrogenibium rodmanii sp. nov., a Sulfur Oxidizing Chemolithoautotroph from the Uzon Caldera, Kamchatka Peninsula, Russia, and Emended Description of the Genus Sulfurihydrogenibium. Int J Syst Evol Microbiol 2008, 58:1147-1152.

29. Nakagawa S, Shtaih Z, Banta A, Beveridge TJ, Sako Y, Reysenbach AL: Sulfurihydrogenibium yellowstonense sp. nov., an extremely thermophilic, facultatively heterotrophic, sulfur-oxidizing bacterium from Yellowstone National Park, and emended descriptions of the genus Sulfurihydrogenibium, Sulfurihydrogenibium subterraneum and Sulfurihydrogenibium azorense. Int J Syst Evol Microbiol 2005, 55:2263-2268

30. Nunoura T, Oida H, Miyazaki M, Suzuki Y: Thermosulfidibacter takaii gen. nov., sp. nov., a thermophilic, hydrogen-oxidizing, sulfur-reducing chemolithoautotroph isolated from a deep-sea hydrothermal field in the Southern Okinawa Trough. Int I Syst Evol Microbiol 2008, 58:659-665.

31. Miroshnichenko ML, Rainey FA, Hippe H, Chernyh NA, Kostrikina NA, BonchOsmolovskaya EA: Desulfurella kamchatkensis sp. nov. and Desulfurella propionica sp. nov., new sulfur-respiring thermophilic bacteria from Kamchatka thermal environments. Int J Syst Bacteriol 1998, 48:475-479.

32. Qiu YL, Hanada S, Ohashi A, Harada H, Kamagata Y, Sekiguchi Y: Syntrophorhabdus aromaticivorans gen. nov., sp. nov., the first cultured 
anaerobe capable of degrading phenol to acetate in obligate syntrophic associations with a hydrogenotrophic methanogen. Appl Environ Microbiol 2008, 74:2051-2058.

33. Sonne-Hansen J, Ahring BK: Thermodesulfobacterium hveragerdense sp. nov., and Thermodesulfovibrio islandicus sp. nov., two thermophilic sulfate reducing bacteria isolated from a Icelandic hot spring. Syst Appl Microbiol 1999, 22:559-564.

34. Portillo M-C, Cuecas A, Pasomsup P, Kanoksilapatham W, Gonzalez J-M: Distribution of baterial communities along a temperature gradient in Mae Fang Hot Springs (Thailand). GenBank Database 2010 [http://www. ncbi.nlm.nih.gov/nuccore/HQ416834.1].

35. Haouari O, Fardeau ML, Cayol JL, Fauque G, Casiot C, Elbaz-Poulichet F, Hamdi M, Ollivier B: Thermodesulfovibrio hydrogeniphilus sp. nov., a new thermophilic sulphate-reducing bacterium isolated from a Tunisian hot spring. Syst Appl Microbiol 2008, 31:38-42.

36. Yan T, Zhu L, Mao Y, Ye N, Zhang X, Fang J: Diversity and distribution of bacterial community composition in Nansha Bay sediment in response to fish cage farming. GenBank Database 2011 [http://www.ncbi.nlm.nih. gov/nuccore/JQ217253.1].

37. Liu R, Li D, Gao Y, Zhang Y, Wu S, Ding R, Hesham AEL, Yang M: Microbial diversity in the anaerobic tank of a full-scale produced water treatment plant. Process Biochem 2010, 45:744-751.

38. Patel BKC, Morgan HW, Daniel RM: Fervidobacterium nodosum gen. nov. and spec. nov., a new hemoorganotrophic, caldoactive, anaerobic bacterium. Arch Microbiol 1985, 141:63-69.

39. Andrews KT, Patel BK: Fervidobacterium gondwanense sp. nov., a new thermophilic anaerobic bacterium isolated from nonvolcanically heated geothermal waters of the Great Artesian Basin of Australia. Int I Syst Bacteriol 1996, 46:265-269.

40. He YL, Ding YF, Long YQ: Two cellulolytic Clostridium species: Clostridium cellulosi sp. nov. and Clostridium cellulofermentans sp. nov. Int J Syst Bacteriol 1991, 41:306-309.

41. Weller R, Bateson MM, Heimbuch BK, Kopczynski ED, Ward DM: Uncultivated cyanobacteria, Chloroflexus-like inhabitants, and spirochete-like inhabitants of a hot spring microbial mat. Appl Environ Microbiol 1992, 58:3964-3969.

42. Daumas S, Cord-Ruwisch R, Garcia JL: Desulfotomaculum geothermicum sp. nov., a thermophilic, fatty acid-degrading, sulfate-reducing bacterium isolated with $\mathrm{H} 2$ from geothermal ground water. Antonie Van Leeuwenhoek 1992, 54:165-178.

43. Miroshnichenko ML, Lebedinsky AV, Chernyh NA, Tourova TP, Kolganova TV, Spring S, Bonch-Osmolovskaya EA: Caldimicrobium rimae gen. nov., sp. nov., an extremely thermophilic, facultatively lithoautotrophic, anaerobic bacterium from the Uzon Caldera, Kamchatka. Int I Syst Evol Microbiol 2009, 59:1040-1044.

44. Albuquerque L, Franca L, Rainey FA, Schumann P, Nobre MF Costa MS: Gaiella occulta gen. nov., sp. nov., a novel representative of a deep branching phylogenetic lineage within the class Actinobacteria and proposal of Gaiellaceae fam. nov. and Gaiellales ord. nov. Syst Appl Microbiol 2011, 34:595-599.

45. Lau MC, Aitchison JC, Pointing SB: Bacterial community composition in thermophilic microbial mats from five hot springs in central Tibet. Extremophiles 2009, 13:139-149.

46. lino T, Nakagawa T, Mori K, Harayama S, Suzuki K: Calditerrivibrio nitroreducens gen. nov., sp. nov., a thermophilic, nitrate-reducing bacterium isolated from a terrestrial hot spring in Japan. Int I Syst Evol Microbiol 2008, 58:1675-1679.

47. Auchtung TA, Shyndriayeva G, Cavanaugh CM: $16 \mathrm{~S}$ rRNA phylogenetic analysis and quantification of Korarchaeota indigenous to the hot springs of Kamchatka, Russia. Extremophiles 2011, 15:105-116.

48. Tomova I, Dimitrova D, Stoilova-Disheva M, Lyutskanova D, Kambourova M: Archael diversity at two hot springs, Rupi Basin, Bulgaria. Biotechnol Biotechnol Equip 2011, 25:105-113.

49. Sahl J-W, Gary M-O, Harris J-K, Spear J-R: A comparative molecular analysis of phreatic limestone sinkholes in northeastern Mexico. GenBank Database 2009 [http://www.ncbi.nlm.nih.gov/nuccore/FJ901693.1].

50. Huang $Q$, Dong $C Z$, Dong RM, Jiang $H$, Wang $S$, Wang G, Fang B, Ding $X$, Niu L, Li X, Zhang C, Dong H: Archaeal and bacterial diversity in hot springs on the Tibetan Plateau, China. Extremophiles 2011, 15:549-563.
51. Pester M, Schleper C, Wagner M: The Thaumarchaeota: an emerging view of their phylogeny and ecophysiology. Curr Opin Microbiol 2011, 14:300-306.

52. Wemheuer B, Taube R, Akyol P, Wemheuer F, Daniel R: Microbial diversity and biochemical potential encoded by thermal spring metagenomes derived from the kamchatka peninsula. Archaea 2013, 136714.

53. Swingley WD, Meyer-Dombard DR, Shock EL, Alsop EB, Falenski HD, Havig JR, Raymond J: Coordinating Environmental Genomics and Geochemistry Reveals Metabolic Transitions in a Hot Spring Ecosystem. PLOS ONE 2012, 7:e38108.

54. Varfolomeev SD: Molecules in extreme environments Tak u ocmaemcg 2013.

55. Kolmogorov YP, Trounova VA: Analytical potential of EDXRF using toroidal focusing systems of highly oriented pyrolytic graphite (HOPG). X-ray Spectrom 2002, 31:432-436.

56. Schmieder R, Edwards R: Quality control and preprocessing of metagenomic datasets. Bioinformatics 2011, 27:863-864.

57. Caporaso JG, Kuczynski J, Stombaugh J, Bittinger K, Bushman FD, Costello EK, Fierer N, Pena AG, Goodrich JK, Gordon Jl, Huttley GA, Kelley ST, Knights D, Koenig JE, Ley RE, Lozupone CA, McDonald D, Muegge BD, Pirrung M, Reeder J, Sevinsky JR, Turnbaugh PJ, Walters WA, Widmann J, Yatsunenko T, Zaneveld J, Knight R: QIIME allows analysis of high-throughput community sequencing data. Nature methods 2010, 7:335-336.

58. Edgar RC: Search and clustering orders of magnitude faster than BLAST. Bioinformatics 2010, 26:2460-2461.

59. Edgar RC, Haas BJ, Clemente JC, Quince C, Knight R: UCHIME improves sensitivity and speed of chimera detection. Bioinformatics 2011, 27:2194-2200.

60. DeSantis TZ, Hugenholtz P, Larsen N, Rojas M, Brodie EL, Keller K, Huber T, Dalevi D, Hu P, Andersen GL: Greengenes, a chimera-checked 16S rRNA gene database and workbench compatible with ARB. Applied and environmental microbiology 2006, 72:5069-5072.

\section{doi:10.1186/1471-2164-15-S12-S12}

Cite this article as: Rozanov et al: Molecular analysis of the benthos microbial community in Zavarzin thermal spring (Uzon Caldera, Kamchatka, Russia). BMC Genomics 2014 15(Suppl 12):S12.

\section{Submit your next manuscript to BioMed Central and take full advantage of:}

- Convenient online submission

- Thorough peer review

- No space constraints or color figure charges

- Immediate publication on acceptance

- Inclusion in PubMed, CAS, Scopus and Google Scholar

- Research which is freely available for redistribution

Submit your manuscript at www.biomedcentral.com/submit
C Biomed Central 